\title{
Sample sizes to estimate mean values for tassel traits in maize genotypes
}

\author{
C.A. Wartha, A. Cargnelutti Filho, A.D. Lúcio, D.N. Follmann, \\ J.A. Kleinpaul and F.M. Simões \\ Department de Fitotecnia, Federal Universidade Federal de Santa Maria, \\ Santa Maria, RS, Brasil \\ Corresponding author: A. Cargnelutti Filho \\ E-mail: alberto.cargnelutti.filho@gmail.com
}

Genet. Mol. Res. 15 (4): gmr15049151

Received September 2, 2016

Accepted September 30, 2016

Published November 21, 2016

DOI http://dx.doi.org/10.4238/gmr15049151

Copyright $(C 2016$ The Authors. This is an open-access article distributed under the terms of the Creative Commons Attribution ShareAlike (CC BY-SA) 4.0 License.

\begin{abstract}
Tassel traits are important in maize breeding programs aiming to reduce the size and number of branches and maintain satisfactory pollen production in order to increase grain yield. The objectives of this study were to determine the sample size (number of tassels) required to estimate the mean values for tassel traits in maize genotypes and to verify the variability of sample size among genotypes. Twenty maize genotypes were evaluated in an experiment carried out in a randomized block design with three replicates. Twenty tassels were randomly collected in each plot, for a total of 1200 tassels. In each tassel, the following traits were measured: peduncle dry matter, branching space dry matter, central spike dry matter, tassel dry matter, peduncle length, branching space length, central spike length, tassel length, tassel dry matter to tassel length ratio, number of primary branches, number of secondary branches, and tassel branch number. Measures of central tendency and variability were calculated, analysis of variance and mean comparison tests were performed, normality was
\end{abstract}


verified, and the sample size was determined. In order to estimate the means with the same precision, the sample size for weight traits was greater than that for length traits. For tassel traits, 11, 20, and 43 tassels are sufficient to estimate the mean with a precision of 40,30 , and $20 \%$, respectively, of the estimated mean at a 95\% confidence level. These data show that there is sample size variability among maize genotypes.

Key words: Zea mays L.; Sampling; Experimental precision; Calculating study sample size

\section{INTRODUCTION}

Maize (Zea mays L.) is one of the most cultivated cereals in the world because of its use in a wide variety of industries, such as feed and foods industries. The estimated world maize production for the 2016/2017 agricultural year is 1013.87 million tons in an area of 178.62 million hectares (FAO, 2016). According to the Food and Agriculture Organization, the United States is the world's largest maize grower, followed by China and Brazil, with an estimated production of 355, 224, and 83 million tons, respectively, in the 2016/2017 agricultural year. The increased grain yield of modern maize cultivars is the result of agronomic practices and genetic gains derived through maize breeding programs (Lauer et al., 2012).

The morphology of staminate and pistillate inflorescences in maize and their separation through the plant favor the study and development of inbred lines and hybrid seed, along with accentuated heterotic responses in the F1 generation (Allard, 1999). For heterosis to occur the genitors should be divergent (Hallauer et al., 2010). In this sense, most maize traits contribute to grain yield, with tassel weight contributing to heterosis in grain yield in diallel crosses (Ribeiro et al., 2014).

Morphological tassel traits are of importance in maize breeding programs, in which inbred lines are developed with the aim of reducing the size and number of branches and maintaining satisfactory pollen production (Duvick, 2005; Fischer and Edmeades, 2010). Larger tassels act as a drain for photoassimilates, which could be directed toward grain production, and restrict the passage of solar radiation through the canopy (Edwards, 2011). In addition, smaller tassels produce lower levels of auxins and decrease apical dominance, which has an inhibitory effect on ear development (Sangoi et al., 2006). In addition to the environment, it permits the production of one or more ear per plant.

Thus, studies evaluating tassel traits related to grain yield have been carried out in half-sib families of an ESALQ-PB1 population (Andrade and Miranda Filho, 2008), in parental lines of Pioneer-brand maize hybrids (Lauer et al., 2012), in recombinant inbred lines in temperate and tropical climates (Brewbaker, 2015), in inbred lines of two heterotic groups (Nardino et al., 2016a), and in F1 hybrids (Nardino et al., 2016b). In general, those studies have confirmed the relationship between tassel traits and grain yield.

In order to generate reliable results from breeding programs involving maize tassels or other agricultural crops, it is important to accurately determine the sample size (number of tassels and/or plants) to be used. As reported by Storck et al. (2016), sampling should be undertaken when it is not possible to evaluate the entire experimental unit. An appropriate sample size enables the population mean to be effectively estimated, reducing the sampling error within the plot and subsequently, the experimental error. Furthermore, Bussab and

Genetics and Molecular Research 15 (4): gmr15049151 
Morettin (2011) stated that the sample size is directly related to data variability and the desired reliability, and that it is inversely related to the level of error previously set by the researcher. Consistent with the above observations, larger sample sizes reduce the experimental error, but increase the demand on the size of the experimental area, manpower, financial resources, and time required for sampling. However, smaller sample sizes increase the experimental error (Cargnelutti Filho et al., 2012; Storck et al., 2016).

In maize, the sample size has been studied to estimate mean values for morphological and productive traits of ears (Martin et al., 2005; Storck et al., 2007), and morphological and productive traits of plants and ears in different soil tillage systems and straw (Modolo et al., 2013). Furthermore, Cargnelutti Filho et al. (2010) established the sample dimension to measure Pearson correlation coefficients among pairs of traits in maize hybrids. Also, the sample size was determined to estimate the coefficient of variation of the mean (Toebe et al., 2014) and Pearson correlation coefficients for different maize hybrids (Toebe et al., 2015).

The above studies presented significant results for the experimental design in maize crops. However, to our knowledge, no studies have investigated sample sizes for the estimation of mean values for tassel traits in maize genotypes, and it is assumed that the sample sizes differ among genotypes. The objectives of the present study were to determine the sample size (number of tassels) required to estimate mean values for tassel traits in maize genotypes and to verify sample size variability among genotypes.

\section{MATERIAL AND METHODS}

An experiment was carried out on maize during the 2015/2016 agricultural year in an experimental area located at $29^{\circ} 42^{\prime} \mathrm{S}, 53^{\circ} 49^{\prime} \mathrm{W}$, and $95 \mathrm{~m}$ in altitude. Based on the Köppen climate classification updated by Peel et al. (2007), the climate of the region is Cfa, humid subtropical, with hot summers and without a dry season (Heldwein et al., 2009). The soil is classified as sandy loam typic Paleudalf (Santos et al., 2013).

Sowing was performed on October 21,2015. The experimental design was a randomized block with 20 genotypes and three replicates, for a total of 60 plots. The 20 genotypes included 18 single-cross hybrids (30A68, 30F53, AG 8780, AG 9025, AM 9724, AS 1666, AS 1677, BM 3066, Celeron, DKB 230, DKB 290, MS 2010, MS 2013, P1630, P2530, SHS 7915, Status VIP, and SX 7331) and two three-way cross hybrids (20A55 and MS 3022). These 20 genotypes were used because they belong to a network of maize cultivars used in evaluation trials to identify genotypes adapted for the State of Rio Grande do Sul, in southern Brazil.

Each plot consisted of two rows, each 5-m long, with spacing of $0.80 \mathrm{~m}$ between rows and $0.20 \mathrm{~m}$ between plants. The plant density was adjusted by manually thinning to five plants per meter of each row, and a final population of 62,500 plants per hectare. Thus, each plot consisted of 50 plants, totaling 3000 plants in the experiment (20 genotypes $\mathrm{x}$ three plots per genotype $\mathrm{x} 50$ plants per plot). Basic fertilizer was applied on the day of sowing, using the commercial NPK formulation at a 5-20-20 proportion, for a total of $37.5 \mathrm{~kg} / \mathrm{ha} \mathrm{N}, 150 \mathrm{~kg} / \mathrm{ha}$ $\mathrm{P}_{2} \mathrm{O}_{5}$, and $150 \mathrm{~kg} / \mathrm{ha} \mathrm{K}_{2} \mathrm{O}$. Posteriorly, topdressing fertilization with $121.5 \mathrm{~kg} / \mathrm{ha} \mathrm{N}$ was divided between three applications, when the plants presented four, six, and eight expanded leaves (November 7 and 23, and December 10, 2015). Cultural practices regarding pest and weed control were followed to maintain competition-free conditions for the crop.

Twenty tassels were randomly collected from each plot and stored in paper packaging 104 days after sowing, when the plants were in the reproductive stage. The packages were

Genetics and Molecular Research 15 (4): gmr15049151 
identified and dried in an oven at $55^{\circ} \mathrm{C}$ until the samples reached constant weight. The following traits were measured in each tassel: peduncle dry matter (PDM, considering the region between the flag leaf collar and the first branch), in grams per tassel; branching space dry matter (BSDM), in grams per tassel; central spike dry matter (CSDM), in grams per tassel; tassel dry matter $(\mathrm{TDM}=\mathrm{PDM}+\mathrm{BSDM}+\mathrm{CSDM})$, in grams per tassel; peduncle length (PL, considering the distance between the collar of the flag leaf and the first branch), in centimeters; branching space length (BSL), in centimeters; central spike length (CSL), in centimeters; tassel length $(\mathrm{TL}=\mathrm{PL}+\mathrm{BSL}+\mathrm{CSL})$, in centimeters; number of primary branches $(\mathrm{NPB})$; number of secondary branches (NSB); and tassel branch number (TBN $=$ NPB + NSB) (Figure 1). Weight traits were measured using a digital scale with precision of $0.01 \mathrm{~g}$. Furthermore, the TDM to tassel length ratio (TDMTL) was calculated in grams per centimeter.

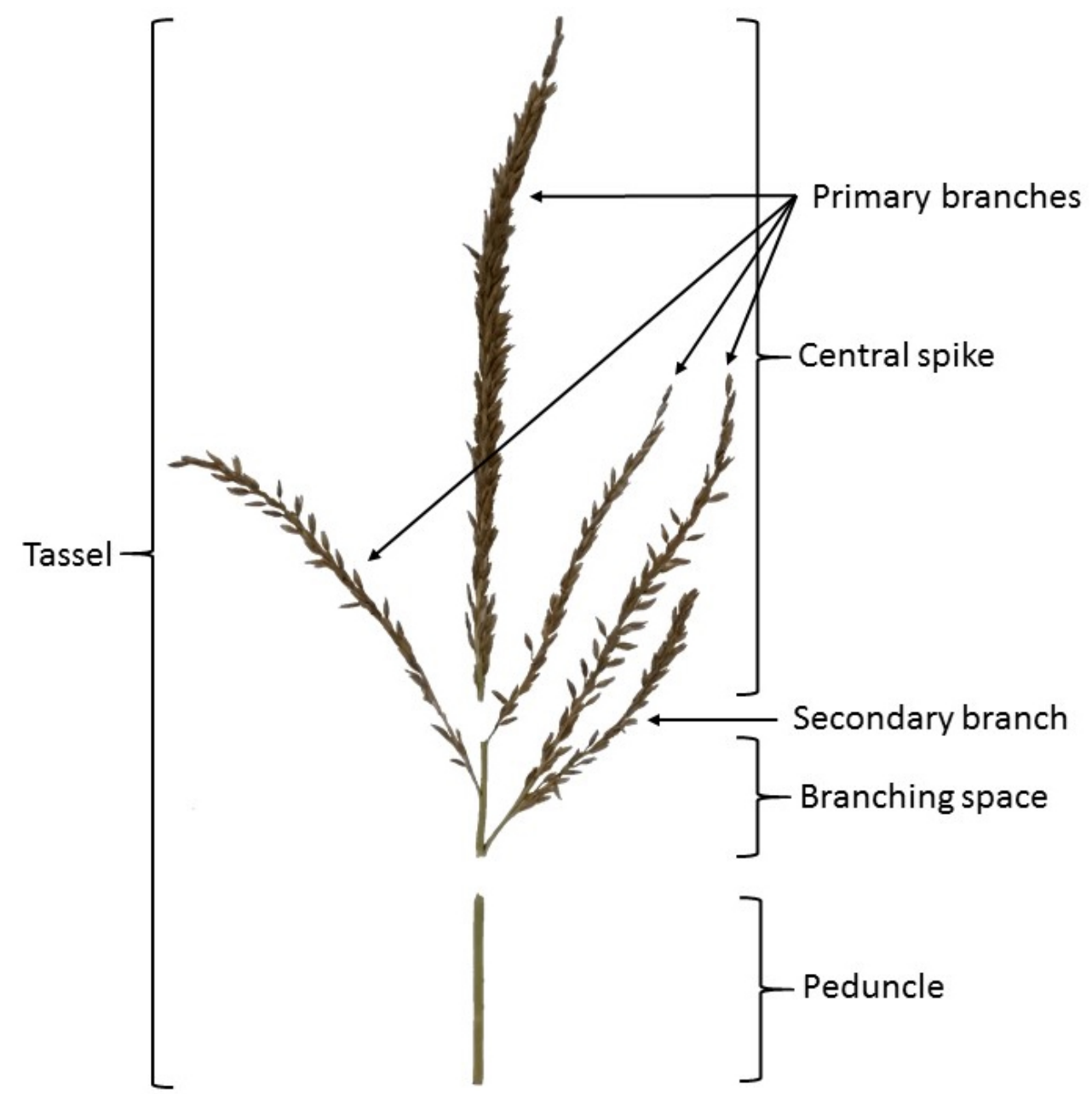

Figure 1. Representation of traits evaluated in a maize tassel from the 30F53 genotype, composed of one central spike, four primary branches, one secondary branch, a branching space, and peduncle, based on the methods described by Upadyayula et al. (2006).

Genetics and Molecular Research 15 (4): gmr15049151 
The data set obtained from the 12 traits was subjected to analysis of variance and $\mathrm{F}$ test at 5\% significance and mean values for genotypes were clustered by the Scott-Knott test (Scott and Knott, 1974) at a 5\% significance level. For analysis of variance, a mathematical model of block design with sampling within plots was used, as defined by Storck et al. (2016). In order to evaluate experimental precision, selective accuracy (SA) (Resende and Duarte, 2007) was determined by the following: $\mathrm{SA}=(1-1 / \mathrm{Fc})^{0.5}$, where $\mathrm{Fc}$ is the value derived from the $\mathrm{F}$ test for the genotype. According to the class limits established by Resende and Duarte (2007), the experimental precision was ranked as very high ( $\mathrm{SA} \geq 0.90)$, high $(0.70 \leq \mathrm{SA}<$ $0.90)$, moderate $(0.50 \leq \mathrm{SA}<0.70)$, and low $(\mathrm{SA}<0.50)$.

Thereafter, normality of the data was verified by the Kolmogorov-Smirnov test (Siegel and Castellan Júnior, 2006) for the traits PDM, BSDM, CSDM, TDM, PL, BSL, CSL, TL, TDMTL, NPB, NSB, and TBN, of 20 tassels from each of the 60 plots, totaling 720 tests (20 genotypes $\mathrm{x}$ three plots per genotype $\mathrm{x} 12$ traits). Normality was investigated in order to verify the suitability of the data set for the study of sample size based on the Student $t$ distribution.

Based on data from 20 tassels sampled from each experimental unit (plot) of each genotype, the sample size (n) for the traits PDM, BSDM, CSDM, TDM, PL, BSL, CSL, TL, TDMTL, NPB, NSB, and TBN was determined using the following equation:

$$
n=t_{\alpha / 2}^{2} C V^{2} / D^{2}
$$

where CV is the coefficient of variation between 20 tassels (\%); D is the semi-amplitude of the confidence interval for the mean (\%) (established as $\mathrm{D}=5,10,20,30$, and $40 \%$ ); and $t$ is the critical value of the Student's $t$ distribution at the 5\% significance level. Thus, 60 variables (sample size) were obtained by the combination of 12 traits (PDM, BSDM, CSDM, TDM, PL, BSL, CSL, TL, TDMTL, NPB, NSB, and TBN) at precision levels of 5\% (D5), 10\% (D10), $20 \%$ (D20), 30\% (D30), and 40\% (D40) of the estimated mean in the experimental unit.

In order to investigate variability in sample size among genotypes, the data set from these 60 variables (sample size) was subjected to analysis of variance using the mathematical model of randomized block design, as described by Storck et al. (2016). Genotype means were clustered using the Scott-Knott test (Scott and Knott, 1974) at a 5\% significance level. Statistical analyzes were performed using the GENES software (Cruz, 2013) and Microsoft Office Excel.

\section{RESULTS AND DISCUSSION}

The mean TDM was $3.11 \mathrm{~g} /$ tassel, tassel length was $47.50 \mathrm{~cm}$, and tassel branch number was 14.00 (Table 1). Similar results were obtained, respectively, by Upadyayula et al. (2006), Lauer et al. (2012), and Brewbaker (2015), proving that there was adequate plant development in the present experiment.

There was a significant effect of genotypes in relation to the 12 traits studied (PDM, BSDM, CSDM, TDM, PL, BSL, CSL, TL, TDMTL, NPB, NSB, and TBN), demonstrating the existence of genetic variability (Table 1). This variability permitted the separation of genotypes into groups by the Scott-Knott test (Table 2). The block effect was not significant, showing that the blocks were not heterogeneous. High $S A$ values $(S A \geq 0.956)$ ensured very high experimental precision in the evaluation of these 12 traits, as stated by Resende and Duarte (2007).

Genetics and Molecular Research 15 (4): gmr15049151 
Table 1. Degrees of freedom (DF) and mean squares of the causes of variation (block, genotype, experimental error, and sampling error), mean, coefficient of experimental variation (CVe), coefficient of sampling variation (CVs), and selective accuracy for tassel traits of 20 maize genotypes.

\begin{tabular}{|c|c|c|c|c|c|c|c|}
\hline \multirow[t]{2}{*}{ Causes of variation } & \multirow[t]{2}{*}{ d.f. } & \multicolumn{6}{|c|}{ Mean square } \\
\hline & & PDM & BSDM & CSDM & TDM & PL & BSL \\
\hline Block & 2 & $0.0053^{\text {ns }}$ & $0.4019^{\text {ns }}$ & $0.0352^{\mathrm{ns}}$ & $0.6155^{\mathrm{ns}}$ & $5.3038^{\mathrm{ns}}$ & $17.3976^{\mathrm{ns}}$ \\
\hline Genotype & 19 & $0.4382 *$ & $39.7248^{*}$ & $1.1918^{*}$ & $47.5530^{*}$ & $207.8687^{*}$ & $380.5366^{*}$ \\
\hline Experimental error & 38 & $0.0195^{*}$ & $1.6080^{*}$ & $0.0500^{*}$ & $2.0325^{*}$ & $17.8210^{*}$ & $16.6530^{*}$ \\
\hline Sampling error & 1140 & 0.0034 & 0.3885 & 0.0176 & 0.5360 & 2.9877 & 3.0543 \\
\hline Mean & - & 0.2592 & 2.1716 & 0.6746 & 3.1053 & 8.7803 & 12.1131 \\
\hline $\mathrm{CVe}(\%)$ & - & 53.92 & 58.39 & 33.14 & 45.91 & 48.08 & 33.69 \\
\hline CVs (\%) & - & 22.49 & 28.70 & 19.68 & 23.58 & 19.69 & 14.43 \\
\hline \multirow[t]{2}{*}{ Selective accuracy } & - & 0.977 & 0.980 & 0.979 & 0.978 & 0.956 & 0.978 \\
\hline & & CSL & $\mathrm{TL}$ & TDMTL & NPB & NSB & TBN \\
\hline Block & 2 & $6.7342^{\mathrm{ns}}$ & $68.9991^{\mathrm{ns}}$ & $0.0001^{\text {ns }}$ & $72.7358^{\mathrm{ns}}$ & $3.4358^{\mathrm{ns}}$ & $106.6975^{\text {ns }}$ \\
\hline Genotype & 19 & $819.5201 *$ & $488.5188^{*}$ & $0.0214 *$ & $1054.1886^{*}$ & $100.1796^{*}$ & $1700.2900 *$ \\
\hline Experimental error & 38 & $12.5195^{*}$ & $29.6708^{*}$ & $0.0009 *$ & $28.2288^{*}$ & $6.3543 *$ & $52.5615^{*}$ \\
\hline Sampling error & 1140 & 6.8588 & 11.5412 & 0.0002 & 4.4512 & 1.1279 & 6.3673 \\
\hline Mean & - & 26.6031 & 47.4964 & 0.0652 & 11.4092 & 2.5933 & 14.0025 \\
\hline$\overline{\mathrm{CVe}(\%)}$ & - & 13.30 & 11.47 & 44.85 & 46.57 & 97.20 & 51.78 \\
\hline CVs (\%) & - & 9.84 & 7.15 & 20.52 & 18.49 & 40.95 & 18.02 \\
\hline Selective accuracy & - & 0.992 & 0.969 & 0.980 & 0.987 & 0.968 & 0.984 \\
\hline
\end{tabular}

$\mathrm{PDM}=$ peduncle dry matter, in grams per tassel; $\mathrm{BSDM}=$ branching space dry matter, in grams per tassel; CSDM = central spike dry matter, in grams per tassel; TDM = tassel dry matter, in grams per tassel; $\mathrm{PL}=$ peduncle length, in centimeters; $\mathrm{BSL}=$ branching space length, in centimeters; $\mathrm{CSL}=$ central spike length, in centimeters; $\mathrm{TL}=$ tassel length, in centimeters; TDMTL $=$ tassel dry matter:tassel length ratio, in grams per centimeter; NPB $=$ number of primary branches, in units; NSB = number of secondary branches, in units; TBN = tassel branch number, in units. *Significant effect as determined by the $\mathrm{F}$ test at a $5 \%$ significance level. ${ }^{\text {ns }}$ Not significant.

The experimental error (variation among plots) was significant in relation to the traits PDM, BSDM, CSDM, TDM, PL, BSL, CSL, TL, TDMTL, NPB, NSB, and TBN (Table 1). Thus, it can be inferred that the coefficients of experimental variation (CVe) were superior to the coefficients of sampling variation (CVs) for all traits. Moreover, these coefficients presented high magnitude, i.e., $11.47 \% \leq \mathrm{CVe} \leq 97.20 \%$, and $7.15 \% \leq \mathrm{CVs} \leq 40.95 \%$. These results show there was greater variability of plants among experimental units than within experimental units. Therefore, increasing the number of replicates is appropriate to improve experimental precision (Barbin, 2003). As reported by Barbin (2003), this method is effective at reducing the estimate of variance of the estimated mean. The high values of CVe and CVs indicate that it is important to adjust the number of replicates and the sample size in order to improve the experimental precision. In this context, Storck et al. (2007) evaluated maize ears and suggested increasing the number of replicates and decreasing the number of ears in the plot, fixing the total number of ears assessed by genotype.

The mean $\mathrm{P}$ value (minimum level of significance) of the Kolmogorov-Smirnov test (Siegel and Castellan Júnior, 2006) relative to the data of 20 tassels in the 720 cases analyzed (20 genotypes x three plots per genotype x 12 traits) was 0.73 . Data of the PDM, BSDM, CSDM, TDM, PL, BSL, CSL, TL, TDMTL, NPB, NSB, and TBN fully adhered to the normal distribution $(\mathrm{P}>0.20)$ in 650 cases $(90.3 \%)$. Considering a minor adjustment, i.e., $\mathrm{P}>0.05,695$ cases $(96.5 \%)$ had an adjusted normal distribution. Therefore, these results indicate that this database is suitable for the study of sample size determination based on the Student $t$ distribution.

Genetics and Molecular Research 15 (4): gmr15049151 
Table 2. Mean values for tassel traits evaluated in 20 maize genotypes.

\begin{tabular}{|c|c|c|c|c|c|c|}
\hline Genotype & PDM & BSDM & CSDM & TDM & PL & BSL \\
\hline $20 \mathrm{~A} 55$ & $0.36^{\mathrm{a}}$ & $3.33^{\mathrm{a}}$ & $0.88^{\mathrm{a}}$ & $4.56^{\mathrm{a}}$ & $10.25^{\mathrm{a}}$ & $14.83^{\mathrm{a}}$ \\
\hline $30 \mathrm{~A} 68$ & $0.33^{\mathrm{b}}$ & $2.08^{\mathrm{c}}$ & $0.77^{\mathrm{b}}$ & $3.19^{\mathrm{c}}$ & $10.03^{\mathrm{a}}$ & $13.2^{\mathrm{b}}$ \\
\hline 30F53 & $0.2^{\mathrm{d}}$ & $1.46^{\mathrm{d}}$ & $0.86^{\mathrm{a}}$ & $2.53^{\mathrm{d}}$ & $6.98^{\mathrm{c}}$ & $9.39^{d}$ \\
\hline AG8780 & $0.36^{\mathrm{a}}$ & $2.25^{\mathrm{c}}$ & $0.48^{\mathrm{c}}$ & $3.09^{\mathrm{c}}$ & $11.34^{\mathrm{a}}$ & $14.92^{\mathrm{a}}$ \\
\hline AG9025 & $0.13^{\mathrm{e}}$ & $1.73^{\mathrm{d}}$ & $0.69^{\mathrm{b}}$ & $2.56^{\mathrm{d}}$ & $5.74^{\mathrm{c}}$ & $10.74^{\mathrm{c}}$ \\
\hline AM9724 & $0.17^{\mathrm{e}}$ & $2.4^{\mathrm{c}}$ & $0.72^{\mathrm{b}}$ & $3.29^{\mathrm{c}}$ & $6.79^{\mathrm{c}}$ & $12.61^{\mathrm{b}}$ \\
\hline AS1666 & $0.26^{\mathrm{c}}$ & $1.36^{\mathrm{d}}$ & $0.69^{\mathrm{b}}$ & $2.32^{\mathrm{d}}$ & $10.2^{\mathrm{a}}$ & $9.09^{d}$ \\
\hline AS1677 & $0.12^{\mathrm{e}}$ & $1.5^{\mathrm{d}}$ & $0.57^{\mathrm{c}}$ & $2.19^{d}$ & $5.55^{\mathrm{c}}$ & $11.37^{\mathrm{c}}$ \\
\hline BM3066 & $0.26^{\mathrm{c}}$ & $3.15^{\mathrm{a}}$ & $0.67^{\mathrm{b}}$ & $4.07^{\mathrm{a}}$ & $7.76^{\mathrm{b}}$ & $13.47^{b}$ \\
\hline Celeron & $0.31^{\mathrm{b}}$ & $1.82^{\mathrm{d}}$ & $0.56^{\mathrm{c}}$ & $2.69^{d}$ & $11.09^{\mathrm{a}}$ & $10.68^{\mathrm{c}}$ \\
\hline DKB230 & $0.12^{\mathrm{e}}$ & $1.19^{\mathrm{e}}$ & $0.33^{\mathrm{d}}$ & $1.65^{\mathrm{e}}$ & $6.3^{\mathrm{c}}$ & $12.7^{\mathrm{b}}$ \\
\hline DKB290 & $0.4^{\mathrm{a}}$ & $2.82^{\mathrm{b}}$ & $0.54^{\mathrm{c}}$ & $3.76^{\mathrm{b}}$ & $11.4^{\mathrm{a}}$ & $15.78^{\mathrm{a}}$ \\
\hline MS2010 & $0.27^{\mathrm{C}}$ & $2.66^{\mathrm{b}}$ & $0.69^{\mathrm{b}}$ & $3.62^{\mathrm{b}}$ & $10.49^{\mathrm{a}}$ & $12.42^{\mathrm{b}}$ \\
\hline MS2013 & $0.24^{\mathrm{c}}$ & $3.41^{\mathrm{a}}$ & $0.86^{\mathrm{a}}$ & $4.5^{\mathrm{a}}$ & $8.25^{\mathrm{b}}$ & $13.15^{\mathrm{b}}$ \\
\hline MS3022 & $0.3^{\mathrm{b}}$ & $2.78^{\mathrm{b}}$ & $0.73^{\mathrm{b}}$ & $3.8^{\mathrm{b}}$ & $8.89^{\mathrm{b}}$ & $10.8^{\mathrm{c}}$ \\
\hline P1630 & $0.2^{\mathrm{d}}$ & $0.72^{\mathrm{e}}$ & $0.75^{\mathrm{b}}$ & $1.67^{\mathrm{e}}$ & $8.7^{\mathrm{b}}$ & $8.32^{\mathrm{d}}$ \\
\hline $\mathrm{P} 2530$ & $0.22^{\mathrm{d}}$ & $0.85^{\mathrm{e}}$ & $0.82^{\mathrm{a}}$ & $1.88^{\mathrm{e}}$ & $8.06^{\mathrm{b}}$ & $7.12^{\mathrm{e}}$ \\
\hline SHS7915 & $0.24^{\mathrm{c}}$ & $2.23^{\mathrm{c}}$ & $0.76^{\mathrm{b}}$ & $3.23^{\mathrm{c}}$ & $8.43^{\mathrm{b}}$ & $10.71^{\mathrm{c}}$ \\
\hline StatusVIP & $0.32^{\mathrm{b}}$ & $2.87^{\mathrm{b}}$ & $0.55^{\mathrm{c}}$ & $3.74^{\mathrm{b}}$ & $8.75^{\mathrm{b}}$ & $15.79^{\mathrm{a}}$ \\
\hline \multirow[t]{2}{*}{ SX7331 } & $0.38^{\mathrm{a}}$ & $2.82^{\mathrm{b}}$ & $0.58^{\mathrm{c}}$ & $3.78^{\mathrm{b}}$ & $10.63^{\mathrm{a}}$ & $15.19^{\mathrm{a}}$ \\
\hline & CSL & $\mathrm{TL}$ & TDMTL & NPB & NSB & TBN \\
\hline 20A55 & $24.55^{\mathrm{e}}$ & $49.63^{\mathrm{c}}$ & $0.09^{\mathrm{a}}$ & $13.47^{\mathrm{b}}$ & $2.72^{\mathrm{b}}$ & $16.18^{\mathrm{b}}$ \\
\hline 30A68 & $31.74^{\mathrm{a}}$ & $54.96^{\mathrm{a}}$ & $0.06^{\mathrm{c}}$ & $9.88^{\mathrm{c}}$ & $2.05^{\mathrm{c}}$ & $11.93^{\mathrm{c}}$ \\
\hline $30 \mathrm{~F} 53$ & $30.89^{b}$ & $47.26^{c}$ & $0.05^{\mathrm{c}}$ & $6.77^{\mathrm{d}}$ & $0.92^{\mathrm{d}}$ & $7.68^{d}$ \\
\hline AG8780 & $22.94^{\mathrm{f}}$ & $49.19^{\mathrm{c}}$ & $0.06^{\mathrm{c}}$ & $11.82^{\mathrm{c}}$ & $3.75^{\mathrm{a}}$ & $15.57^{\mathrm{b}}$ \\
\hline AG9025 & $29.94^{b}$ & $46.42^{d}$ & $0.05^{\mathrm{c}}$ & $8.95^{\mathrm{c}}$ & $1.43^{\mathrm{c}}$ & $10.38^{\mathrm{c}}$ \\
\hline AM9724 & $27.34^{\mathrm{d}}$ & $46.73^{\mathrm{d}}$ & $0.07^{\mathrm{b}}$ & $10.45^{\mathrm{c}}$ & $3.83^{\mathrm{a}}$ & $14.28^{\mathrm{b}}$ \\
\hline AS1666 & $28.81^{\mathrm{c}}$ & $48.11^{\mathrm{c}}$ & $0.05^{\mathrm{c}}$ & $6.73^{\mathrm{d}}$ & $1.65^{\mathrm{c}}$ & $8.38^{\mathrm{d}}$ \\
\hline AS1677 & $28.16^{\mathrm{c}}$ & $45.09^{\mathrm{e}}$ & $0.05^{\mathrm{c}}$ & $8.05^{\mathrm{d}}$ & $1.8^{\mathrm{c}}$ & $9.85^{\mathrm{c}}$ \\
\hline BM3066 & $21.35^{\mathrm{g}}$ & $42.58^{\mathrm{e}}$ & $0.09^{\mathrm{a}}$ & $18.63^{\mathrm{a}}$ & $3.72^{\mathrm{a}}$ & $22.35^{\mathrm{a}}$ \\
\hline Celeron & $26.97^{\mathrm{d}}$ & $48.74^{c}$ & $0.05^{\mathrm{c}}$ & $11.07^{\mathrm{c}}$ & $2.05^{\mathrm{c}}$ & $13.12^{\mathrm{c}}$ \\
\hline DKB230 & $24.78^{\mathrm{e}}$ & $43.78^{\mathrm{e}}$ & $0.04^{\mathrm{d}}$ & $10.1^{\mathrm{c}}$ & $2.5^{\mathrm{b}}$ & $12.6^{\mathrm{c}}$ \\
\hline DKB290 & $21.48^{\mathrm{g}}$ & $48.66^{\mathrm{c}}$ & $0.08^{\mathrm{b}}$ & $12.7^{\mathrm{b}}$ & $3.9^{\mathrm{a}}$ & $16.6^{\mathrm{b}}$ \\
\hline MS2010 & $28.71^{\mathrm{c}}$ & $51.62^{b}$ & $0.07^{\mathrm{b}}$ & $14.93^{\mathrm{b}}$ & $3.77^{\mathrm{a}}$ & $18.7^{\mathrm{b}}$ \\
\hline MS2013 & $26.6^{\mathrm{d}}$ & $47.99^{c}$ & $0.09^{\mathrm{a}}$ & $14.18^{\mathrm{b}}$ & $4^{\mathrm{a}}$ & $18.18^{\mathrm{b}}$ \\
\hline MS3022 & $24.87^{\mathrm{e}}$ & $44.57^{\mathrm{e}}$ & $0.08^{\mathrm{a}}$ & $13.4^{\mathrm{b}}$ & $3.23^{\mathrm{b}}$ & $16.63^{\mathrm{b}}$ \\
\hline P1630 & $30.71^{\mathrm{b}}$ & $47.73^{c}$ & $0.04^{\mathrm{d}}$ & $6.4^{\mathrm{d}}$ & $0.27^{\mathrm{d}}$ & $6.67^{d}$ \\
\hline P2530 & $32.23^{\mathrm{a}}$ & $47.41^{\mathrm{c}}$ & $0.04^{\mathrm{d}}$ & $4.55^{\mathrm{e}}$ & $0^{\mathrm{d}}$ & $4.55^{\mathrm{e}}$ \\
\hline SHS7915 & $27.41^{\mathrm{d}}$ & $46.54^{\mathrm{d}}$ & $0.07^{\mathrm{b}}$ & $8.85^{\mathrm{c}}$ & $2.57^{\mathrm{b}}$ & $11.42^{\mathrm{c}}$ \\
\hline StatusVIP & $19.31^{\mathrm{h}}$ & $43.84^{\mathrm{e}}$ & $0.08^{\mathrm{a}}$ & $19.82^{\mathrm{a}}$ & $4.35^{\mathrm{a}}$ & $24.17^{\mathrm{a}}$ \\
\hline SX7331 & $23.29^{f}$ & $49.11^{\mathrm{c}}$ & $0.08^{\mathrm{b}}$ & $17.43^{\mathrm{a}}$ & $3.37^{\mathrm{a}}$ & $20.8^{\mathrm{a}}$ \\
\hline
\end{tabular}

$\mathrm{PDM}=$ peduncle dry matter, in grams per tassel; $\mathrm{BSDM}=$ branching space dry matter, in grams per tassel; $\mathrm{CSDM}=$ central spike dry matter, in grams per tassel; TDM = tassel dry matter, in grams per tassel; $\mathrm{PL}=$ peduncle length, in centimeters; $\mathrm{BSL}=$ branching space length, in centimeters; $\mathrm{CSL}=$ central spike length, in centimeters; $\mathrm{TL}=$ tassel length, in centimeters; TDMTL $=$ tassel dry matter:tassel length ratio, in grams per centimeter; NPB $=$ number of primary branches, in units; NSB = number of secondary branches, in units; TBN $=$ tassel branch number, in units. Means not followed by the same superscript letter differ by the Scott-Knott test at a 5\% significance level.

The results of analysis of variance of the sample size, and those of the Scott-Knott test, in relation to the 12 studied traits (PDM, BSDM, CSDM, TDM, PL, BSL, CSL, TL, TDMTL, NPB, NSB, and TBN) are shown in Tables 3, 4, 5, and 6. Regarding the analysis of variance of the sample size, the effect of genotypes was not found to be significant for the traits BSDM and TDMTL (Table 3). Consequently, as expected, no statistical differences were detected by the Scott-Knott test in terms of the sample sizes of those traits. Therefore, the average size for those traits is representative of all genotypes. Thus, 32 tassels per experimental unit for BSDM 
(Table 4) and 17 tassels per experimental unit for TDMTL (Table 6) are sufficient to obtain estimates of the genotype mean with a precision of $10 \%$ (D10).

Table3. Causes of variation (block and genotype) and respective degrees of freedom(DF), F test value for genotype $(\mathrm{Fc})$, and coefficient of variation (CV) of sample sizes (number of tassels) for tassel traits in 20 maize genotypes.

\begin{tabular}{|c|c|c|c|c|c|c|}
\hline Causes of variation & PDM & BSDM & CSDM & TDM & PL & $\mathrm{BSL}$ \\
\hline Block (d.f. $=2)$ & ns & ns & ns & ns & ns & $\mathrm{ns}$ \\
\hline Genotype (d.f. $=19$ ) & $*$ & ns & $*$ & $*$ & * & * \\
\hline $\mathrm{Fc}$ & 7.13 & 1.67 & 3.41 & 2.69 & 6.21 & 4.29 \\
\hline \multirow[t]{2}{*}{$\mathrm{CV}(\%)$} & 35.19 & 41.47 & 30.54 & 41.41 & 48.39 & 39.83 \\
\hline & $\mathrm{CSL}$ & $\mathrm{TL}$ & TDMTL & NPB & NSB & TBN \\
\hline Block $($ d.f. $=2)$ & ns & ns & ns & ns & ns & ns \\
\hline Genotype (d.f. $=19$ ) & $*$ & $*$ & ns & * & $*$ & $*$ \\
\hline $\mathrm{Fc}$ & 2.45 & 3.76 & 1.62 & 2.75 & 6.70 & 3.10 \\
\hline $\mathrm{CV}(\%)$ & 40.72 & 38.25 & 50.82 & 40.56 & 138.63 & 43.91 \\
\hline
\end{tabular}

$\mathrm{PDM}=$ peduncle dry matter, in grams per tassel; $\mathrm{BSDM}=$ branching space dry matter, in grams per tassel; $\mathrm{CSDM}=$ central spike dry matter, in grams per tassel; TDM = tassel dry matter, in grams per tassel; $\mathrm{PL}=$ peduncle length, in centimeters; $\mathrm{BSL}=$ branching space length, in centimeters; $\mathrm{CSL}=$ central spike length, in centimeters; $\mathrm{TL}=$ tassel length, in centimeters; TDMTL = tassel dry matter:tassel length ratio, in grams per centimeter; NPB = number of primary branches, in units; NSB = number of secondary branches, in units; TBN = tassel branch number, in units.

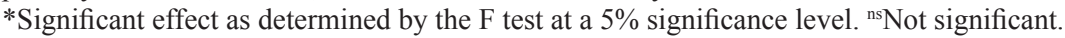

For the other 10 traits, the effect of genotypes was significant, which demonstrates distinct sample sizes among genotypes (Table 3 ). Thus, four sample size groups were formed for PDM, three groups for CSDM and PL, and two for TDM, BSL, CSL, TL, NPB, NSB, and TBN by the Scott-Knott test, confirming that different sample sizes among genotypes are required to estimate the mean of these traits with the same precision (Tables 4, 5, and 6). Therefore, it can be inferred that there is sample size variability among genotypes, as verified in maize (Martin et al., 2005; Storck et al., 2007; Toebe et al., 2015). In this context, Martin et al. (2005) suggested sampling each genotype with its respective sample size or using the largest sample size determined in order to cover all genotypes.

The sample size used to estimate the mean of each trait, with semi-amplitude of the confidence interval equal to $5 \%$ of the mean estimate (greater precision, in this study), and a $95 \%$ confidence level, ranged from four tassels for TL of the 30A68 genotype to 6251 tassels for NSB of the P1630 genotype (Tables 4, 5, and 6). These results confirm the presence of sample size variability among traits of maize genotypes, as verified among traits (Storck et al., 2007; Toebe et al., 2014) and between pairs of traits in maize (Cargnelutti Filho et al., 2010; Toebe et al., 2015). In line with this, Storck et al. (2007) suggested using the sample size determined for the most important trait for the experiment. Another possibility proposed by those authors is to take an average sample size per group of traits, which includes the largest number of traits.

If a researcher utilizes the same sample size to evaluate these traits in an experiment, greater precision in estimates will be obtained in relation to TL, decreasing gradually in the following order: CSL, BSL, TBN, NPB, TDMTL, CSDM, PL, TDM, PDM, BSDM, and NSB. Under the general conditions of the present experiment, the data set demonstrated that to estimate the mean with the same precision, the sample size for weight traits is greater than that for length traits. Cargnelutti Filho et al. (2012) also observed the necessity of a larger sample size to evaluate weight traits in relation to other traits (length and diameter) in jack bean and velvet bean seeds. 
Table 4. Sample size (number of tassels) of 20 maize genotypes for semi-amplitudes of the interval with $95 \%$ confidence equals to 5\% (D5), 10\% (D10), 20\% (D20), 30\% (D30), and 40\% (D40) of the mean in relation to the traits peduncle dry matter, branching space dry matter, central spike dry matter, and tassel dry matter.

\begin{tabular}{|c|c|c|c|c|c|c|c|c|c|c|}
\hline \multirow[t]{2}{*}{ Genotype } & \multicolumn{5}{|c|}{ Peduncle dry matter } & \multicolumn{5}{|c|}{ Branching space dry matter } \\
\hline & D5 & D10 & D20 & D30 & D40 & D5 & D10 & D20 & D30 & $\mathrm{D} 40$ \\
\hline $20 \mathrm{~A} 55$ & $95^{\mathrm{c}}$ & 24 & 6 & 3 & 2 & 142 & 36 & 9 & 4 & 3 \\
\hline $30 \mathrm{~A} 68$ & $85^{\mathrm{c}}$ & 22 & 6 & 3 & 2 & 148 & 37 & 10 & 5 & 3 \\
\hline 30F53 & $46^{\mathrm{d}}$ & 12 & 3 & 2 & 1 & 85 & 22 & 6 & 3 & 2 \\
\hline AG8780 & $54^{\mathrm{d}}$ & 14 & 4 & 2 & 1 & 98 & 25 & 7 & 3 & 2 \\
\hline AG9025 & $233^{\mathrm{a}}$ & 59 & 15 & 7 & 4 & 150 & 38 & 10 & 5 & 3 \\
\hline AM9724 & $135^{\mathrm{b}}$ & 34 & 9 & 4 & 3 & 169 & 43 & 11 & 5 & 3 \\
\hline AS1666 & $113^{\mathrm{c}}$ & 29 & 8 & 4 & 2 & 76 & 19 & 5 & 3 & 2 \\
\hline AS1677 & $213^{\mathrm{a}}$ & 54 & 14 & 6 & 4 & 112 & 28 & 7 & 4 & 2 \\
\hline BM3066 & $162^{b}$ & 41 & 11 & 5 & 3 & 143 & 36 & 9 & 4 & 3 \\
\hline Celeron & $61^{\mathrm{d}}$ & 16 & 4 & 2 & 1 & 108 & 27 & 7 & 3 & 2 \\
\hline DKB230 & $171^{\mathrm{b}}$ & 43 & 11 & 5 & 3 & 106 & 27 & 7 & 3 & 2 \\
\hline DKB290 & $36^{\mathrm{d}}$ & 9 & 3 & 1 & 1 & 103 & 26 & 7 & 3 & 2 \\
\hline MS2010 & $76^{\mathrm{c}}$ & 19 & 5 & 3 & 2 & 201 & 51 & 13 & 6 & 4 \\
\hline MS2013 & $90^{\mathrm{c}}$ & 23 & 6 & 3 & 2 & 105 & 27 & 7 & 3 & 2 \\
\hline MS3022 & $118^{\mathrm{c}}$ & 30 & 8 & 4 & 2 & 126 & 32 & 8 & 4 & 2 \\
\hline P1630 & $144^{\mathrm{b}}$ & 36 & 9 & 4 & 3 & 144 & 36 & 9 & 4 & 3 \\
\hline P2530 & $87^{\mathrm{c}}$ & 22 & 6 & 3 & 2 & 87 & 22 & 6 & 3 & 2 \\
\hline SHS7915 & $138^{\mathrm{b}}$ & 35 & 9 & 4 & 3 & 220 & 55 & 14 & 7 & 4 \\
\hline StatusVIP & $39^{\mathrm{d}}$ & 10 & 3 & 2 & 1 & 108 & 27 & 7 & 3 & 2 \\
\hline SX7331 & $37^{\mathrm{d}}$ & 10 & 3 & 2 & 1 & 86 & 22 & 6 & 3 & 2 \\
\hline \multirow[t]{3}{*}{ Mean } & 107 & 28 & 8 & 4 & 3 & 126 & 32 & 9 & 4 & 3 \\
\hline & \multicolumn{5}{|c|}{ Central spike dry matter } & \multicolumn{5}{|c|}{ Tassel dry matter } \\
\hline & D5 & D10 & D20 & D30 & D40 & D5 & D10 & D20 & D30 & $\mathrm{D} 40$ \\
\hline $20 \mathrm{~A} 55$ & $72^{\mathrm{c}}$ & 18 & 5 & 2 & 2 & $103^{\mathrm{a}}$ & 26 & 7 & 3 & 2 \\
\hline $30 \mathrm{~A} 68$ & $50^{\mathrm{c}}$ & 13 & 4 & 2 & 1 & $84^{\mathrm{b}}$ & 21 & 6 & 3 & 2 \\
\hline $30 \mathrm{~F} 53$ & $43^{\mathrm{c}}$ & 11 & 3 & 2 & 1 & $47^{b}$ & 12 & 3 & 2 & 1 \\
\hline AG8780 & $77^{\mathrm{b}}$ & 20 & 5 & 3 & 2 & $76^{\mathrm{b}}$ & 19 & 5 & 3 & 2 \\
\hline AG9025 & $47^{\mathrm{c}}$ & 12 & 3 & 2 & 1 & $84^{\mathrm{b}}$ & 21 & 6 & 3 & 2 \\
\hline AM9724 & $67^{\mathrm{c}}$ & 17 & 5 & 2 & 2 & $122^{\mathrm{a}}$ & 31 & 8 & 4 & 2 \\
\hline AS1666 & $39^{\mathrm{c}}$ & 10 & 3 & 2 & 1 & $46^{\mathrm{b}}$ & 12 & 3 & 2 & 1 \\
\hline AS1677 & $61^{\mathrm{c}}$ & 16 & 4 & 2 & 1 & $73^{b}$ & 19 & 5 & 3 & 2 \\
\hline BM3066 & $77^{\mathrm{b}}$ & 20 & 5 & 3 & 2 & $115^{\mathrm{a}}$ & 29 & 8 & 4 & 2 \\
\hline Celeron & $59^{\mathrm{c}}$ & 15 & 4 & 2 & 1 & $70^{\mathrm{b}}$ & 18 & 5 & 2 & 2 \\
\hline DKB230 & $56^{\mathrm{c}}$ & 14 & 4 & 2 & 1 & $69^{\mathrm{b}}$ & 18 & 5 & 2 & 2 \\
\hline DKB290 & $57^{\mathrm{c}}$ & 15 & 4 & 2 & 1 & $73^{b}$ & 19 & 5 & 3 & 2 \\
\hline MS2010 & $130^{\mathrm{a}}$ & 33 & 9 & 4 & 3 & $153^{\mathrm{a}}$ & 39 & 10 & 5 & 3 \\
\hline MS2013 & $85^{\mathrm{b}}$ & 22 & 6 & 3 & 2 & $83^{\mathrm{b}}$ & 21 & 6 & 3 & 2 \\
\hline MS3022 & $67^{\mathrm{c}}$ & 17 & 5 & 2 & 2 & $94^{\mathrm{b}}$ & 24 & 6 & 3 & 2 \\
\hline P1630 & $81^{\mathrm{b}}$ & 21 & 6 & 3 & 2 & $50^{\mathrm{b}}$ & 13 & 4 & 2 & 1 \\
\hline P2530 & $37^{\mathrm{c}}$ & 10 & 3 & 2 & 1 & $36^{\mathrm{b}}$ & 9 & 3 & 1 & 1 \\
\hline SHS7915 & $92^{\mathrm{b}}$ & 23 & 6 & 3 & 2 & $158^{\mathrm{a}}$ & 40 & 10 & 5 & 3 \\
\hline StatusVIP & $58^{\mathrm{c}}$ & 15 & 4 & 2 & 1 & $82^{b}$ & 21 & 6 & 3 & 2 \\
\hline SX7331 & $60^{\mathrm{c}}$ & 15 & 4 & 2 & 1 & $64^{b}$ & 16 & 4 & 2 & 1 \\
\hline Mean & 66 & 17 & 5 & 3 & 2 & 85 & 22 & 6 & 3 & 2 \\
\hline
\end{tabular}

Means not followed by the same letter differ by the Scott-Knott test at a 5\% significance level. In columns referring to D10, D20, D30, and D40, the superscript letters are the same as in the column referring to D5, and therefore were not placed.

Genetics and Molecular Research 15 (4): gmr15049151 
Table 5. Sample size (number of tassels) of 20 maize genotypes for semi-amplitudes of the interval with $95 \%$ confidence equals to 5\% (D5), 10\% (D10), 20\% (D20), 30\% (D30), and 40\% (D40) of the mean in relation to the traits peduncle length, branching space length, central spike length, and tassel length.

\begin{tabular}{|c|c|c|c|c|c|c|c|c|c|c|}
\hline \multirow[t]{2}{*}{ Genotype } & \multicolumn{5}{|c|}{ Peduncle length } & \multicolumn{5}{|c|}{ Branching space length } \\
\hline & D5 & D10 & D20 & D30 & D40 & D5 & D10 & D20 & D30 & D40 \\
\hline $20 \mathrm{~A} 55$ & $85^{\mathrm{c}}$ & 22 & 6 & 3 & 2 & $42^{\mathrm{b}}$ & 11 & 3 & 2 & 1 \\
\hline $30 \mathrm{~A} 68$ & $52^{\mathrm{c}}$ & 13 & 4 & 2 & 1 & $40^{\mathrm{b}}$ & 10 & 3 & 2 & 1 \\
\hline 30F53 & $54^{\mathrm{c}}$ & 14 & 4 & 2 & 1 & $40^{\mathrm{b}}$ & 10 & 3 & 2 & 1 \\
\hline AG8780 & $22^{\mathrm{c}}$ & 6 & 2 & 1 & 1 & $24^{\mathrm{b}}$ & 6 & 2 & 1 & 1 \\
\hline AG9025 & $172^{\mathrm{a}}$ & 43 & 11 & 5 & 3 & $66^{\mathrm{a}}$ & 17 & 5 & 2 & 2 \\
\hline AM9724 & $89^{c}$ & 23 & 6 & 3 & 2 & $36^{\mathrm{b}}$ & 9 & 3 & 1 & 1 \\
\hline AS1666 & $53^{\mathrm{c}}$ & 14 & 4 & 2 & 1 & $32^{\mathrm{b}}$ & 8 & 2 & 1 & 1 \\
\hline AS1677 & $188^{\mathrm{a}}$ & 47 & 12 & 6 & 3 & $53^{\mathrm{b}}$ & 14 & 4 & 2 & 1 \\
\hline BM3066 & $114^{b}$ & 29 & 8 & 4 & 2 & $20^{\mathrm{b}}$ & 5 & 2 & 1 & 1 \\
\hline Celeron & $26^{\mathrm{c}}$ & 7 & 2 & 1 & 1 & $32^{\mathrm{b}}$ & 8 & 2 & 1 & 1 \\
\hline DKB230 & $208^{\mathrm{a}}$ & 52 & 13 & 6 & 4 & $33^{\mathrm{b}}$ & 9 & 3 & 1 & 1 \\
\hline DKB290 & $29^{\mathrm{c}}$ & 8 & 2 & 1 & 1 & $25^{\mathrm{b}}$ & 7 & 2 & 1 & 1 \\
\hline MS2010 & $31^{\mathrm{c}}$ & 8 & 2 & 1 & 1 & $53^{\mathrm{b}}$ & 14 & 4 & 2 & 1 \\
\hline MS2013 & $111^{\mathrm{b}}$ & 28 & 7 & 4 & 2 & $44^{\mathrm{b}}$ & 11 & 3 & 2 & 1 \\
\hline MS3022 & $85^{\mathrm{c}}$ & 22 & 6 & 3 & 2 & $48^{\mathrm{b}}$ & 12 & 3 & 2 & 1 \\
\hline P1630 & $152^{\mathrm{a}}$ & 38 & 10 & 5 & 3 & $80^{\mathrm{a}}$ & 20 & 5 & 3 & 2 \\
\hline P2530 & $64^{c}$ & 16 & 4 & 2 & 1 & $89^{\mathrm{a}}$ & 23 & 6 & 3 & 2 \\
\hline SHS7915 & $72^{\mathrm{c}}$ & 18 & 5 & 2 & 2 & $42^{\mathrm{b}}$ & 11 & 3 & 2 & 1 \\
\hline StatusVIP & $31^{\mathrm{c}}$ & 8 & 2 & 1 & 1 & $16^{\mathrm{b}}$ & 4 & 1 & 1 & 1 \\
\hline SX7331 & $25^{\mathrm{c}}$ & 7 & 2 & 1 & 1 & $16^{\mathrm{b}}$ & 4 & 1 & 1 & 1 \\
\hline \multirow[t]{3}{*}{ Mean } & 84 & 22 & 6 & 3 & 2 & 42 & 11 & 3 & 2 & 2 \\
\hline & \multicolumn{5}{|c|}{$\frac{1}{\text { Central spike length }}$} & \multicolumn{5}{|c|}{ Tassel length } \\
\hline & D5 & D10 & D20 & D30 & D40 & D5 & D10 & D20 & D30 & D40 \\
\hline $20 \mathrm{~A} 55$ & $20^{\mathrm{a}}$ & 5 & 2 & 1 & 1 & $12^{\mathrm{a}}$ & 3 & 1 & 1 & 1 \\
\hline $30 \mathrm{~A} 68$ & $11^{\mathrm{b}}$ & 3 & 1 & 1 & 1 & $4^{\mathrm{b}}$ & 1 & 1 & 1 & 1 \\
\hline $30 \mathrm{~F} 53$ & $12^{\mathrm{b}}$ & 3 & 1 & 1 & 1 & $5^{\mathrm{b}}$ & 2 & 1 & 1 & 1 \\
\hline AG8780 & $25^{\mathrm{a}}$ & 7 & 2 & 1 & 1 & $9^{\mathrm{b}}$ & 3 & 1 & 1 & 1 \\
\hline AG9025 & $7^{b}$ & 2 & 1 & 1 & 1 & $7^{\mathrm{b}}$ & 2 & 1 & 1 & 1 \\
\hline AM9724 & $18^{\mathrm{b}}$ & 5 & 2 & 1 & 1 & $9^{b}$ & 3 & 1 & 1 & 1 \\
\hline AS1666 & $8^{\mathrm{b}}$ & 2 & 1 & 1 & 1 & $7^{b}$ & 2 & 1 & 1 & 1 \\
\hline AS1677 & $17^{\mathrm{b}}$ & 5 & 2 & 1 & 1 & $7^{\mathrm{b}}$ & 2 & 1 & 1 & 1 \\
\hline BM3066 & $18^{\mathrm{b}}$ & 5 & 2 & 1 & 1 & $10^{\mathrm{b}}$ & 3 & 1 & 1 & 1 \\
\hline Celeron & $14^{\mathrm{b}}$ & 4 & 1 & 1 & 1 & $6^{\mathrm{b}}$ & 2 & 1 & 1 & 1 \\
\hline DKB230 & $14^{\mathrm{b}}$ & 4 & 1 & 1 & 1 & $13^{\mathrm{a}}$ & 4 & 1 & 1 & 1 \\
\hline DKB290 & $21^{\mathrm{a}}$ & 6 & 2 & 1 & 1 & $10^{\mathrm{b}}$ & 3 & 1 & 1 & 1 \\
\hline MS2010 & $29^{\mathrm{a}}$ & 8 & 2 & 1 & 1 & $17^{\mathrm{a}}$ & 5 & 2 & 1 & 1 \\
\hline MS2013 & $19^{\mathrm{a}}$ & 5 & 2 & 1 & 1 & $9^{b}$ & 3 & 1 & 1 & 1 \\
\hline MS3022 & $27^{\mathrm{a}}$ & 7 & 2 & 1 & 1 & $16^{\mathrm{a}}$ & 4 & 1 & 1 & 1 \\
\hline P1630 & $22^{\mathrm{a}}$ & 6 & 2 & 1 & 1 & $11^{\mathrm{b}}$ & 3 & 1 & 1 & 1 \\
\hline P2530 & $11^{\mathrm{b}}$ & 3 & 1 & 1 & 1 & $10^{\mathrm{b}}$ & 3 & 1 & 1 & 1 \\
\hline SHS7915 & $28^{\mathrm{a}}$ & 7 & 2 & 1 & 1 & $17^{\mathrm{a}}$ & 5 & 2 & 1 & 1 \\
\hline StatusVIP & $20^{\mathrm{a}}$ & 5 & 2 & 1 & 1 & $7^{b}$ & 2 & 1 & 1 & 1 \\
\hline SX7331 & $16^{\mathrm{b}}$ & 4 & 1 & 1 & 1 & $5^{\mathrm{b}}$ & 2 & 1 & 1 & 1 \\
\hline Mean & 18 & 5 & 2 & 1 & 1 & 10 & 3 & 2 & 1 & 1 \\
\hline
\end{tabular}

Means not followed by the same superscript letter differ by the Scott-Knott test at $5 \%$ significance level. In columns referring to D10, D20, D30, and D40, the letters are the same as in the column referring to D5, and therefore, are not shown.

Genetics and Molecular Research 15 (4): gmr15049151 
Table 6. Sample size (number of tassels) of 20 maize genotypes for semi-amplitudes of the interval with $95 \%$ confidence equals to $5 \%$ (D5), $10 \%$ (D10), 20\% (D20), 30\% (D30), and 40\% (D40) of the mean in relation to the traits tassel dry matter by tassel length ratio, number of primary branches, number of secondary branches, and tassel branch number.

\begin{tabular}{|c|c|c|c|c|c|c|c|c|c|c|}
\hline \multirow[t]{2}{*}{ Genotype } & \multicolumn{5}{|c|}{ Tassel dry matter: tassel length ratio } & \multicolumn{5}{|c|}{ Number of primary branches } \\
\hline & D5 & D10 & $\mathrm{D} 20$ & $\mathrm{D} 30$ & D40 & D5 & D10 & $\mathrm{D} 20$ & D30 & $\mathrm{D} 40$ \\
\hline $20 \mathrm{~A} 55$ & 82 & 21 & 6 & 3 & 2 & $102^{\mathrm{a}}$ & 26 & 7 & 3 & 2 \\
\hline $30 \mathrm{~A} 68$ & 70 & 18 & 5 & 2 & 2 & $77^{\mathrm{a}}$ & 20 & 5 & 3 & 2 \\
\hline $30 \mathrm{~F} 53$ & 39 & 10 & 3 & 2 & 1 & $91^{\mathrm{a}}$ & 23 & 6 & 3 & 2 \\
\hline AG8780 & 51 & 13 & 4 & 2 & 1 & $38^{\mathrm{b}}$ & 10 & 3 & 2 & 1 \\
\hline AG9025 & 70 & 18 & 5 & 2 & 2 & $97^{\mathrm{a}}$ & 25 & 7 & 3 & 2 \\
\hline AM9724 & 113 & 29 & 8 & 4 & 2 & $56^{\mathrm{b}}$ & 14 & 4 & 2 & 1 \\
\hline AS1666 & 36 & 9 & 3 & 1 & 1 & $47^{\mathrm{b}}$ & 12 & 3 & 2 & 1 \\
\hline AS1677 & 65 & 17 & 5 & 2 & 2 & $77^{\mathrm{a}}$ & 20 & 5 & 3 & 2 \\
\hline BM3066 & 84 & 21 & 6 & 3 & 2 & $50^{\mathrm{b}}$ & 13 & 4 & 2 & 1 \\
\hline Celeron & 57 & 15 & 4 & 2 & 1 & $37^{\mathrm{b}}$ & 10 & 3 & 2 & 1 \\
\hline DKB230 & 44 & 11 & 3 & 2 & 1 & $55^{\mathrm{b}}$ & 14 & 4 & 2 & 1 \\
\hline DKB290 & 61 & 16 & 4 & 2 & 1 & $18^{\mathrm{b}}$ & 5 & 2 & 1 & 1 \\
\hline MS2010 & 110 & 28 & 7 & 4 & 2 & $65^{\mathrm{a}}$ & 17 & 5 & 2 & 2 \\
\hline MS2013 & 62 & 16 & 4 & 2 & 1 & $45^{\mathrm{b}}$ & 12 & 3 & 2 & 1 \\
\hline MS3022 & 59 & 15 & 4 & 2 & 1 & $69^{\mathrm{a}}$ & 18 & 5 & 2 & 2 \\
\hline P1630 & 43 & 11 & 3 & 2 & 1 & $95^{\mathrm{a}}$ & 24 & 6 & 3 & 2 \\
\hline P2530 & 33 & 9 & 3 & 1 & 1 & $76^{\mathrm{a}}$ & 19 & 5 & 3 & 2 \\
\hline SHS7915 & 108 & 27 & 7 & 3 & 2 & $57^{\mathrm{b}}$ & 15 & 4 & 2 & 1 \\
\hline StatusVIP & 58 & 15 & 4 & 2 & 1 & $37^{\mathrm{b}}$ & 10 & 3 & 2 & 1 \\
\hline SX7331 & 48 & 12 & 3 & 2 & 1 & $37^{\mathrm{b}}$ & 10 & 3 & 2 & 1 \\
\hline \multirow[t]{3}{*}{ Mean } & 65 & 17 & 5 & 3 & 2 & 62 & 16 & 5 & 3 & 2 \\
\hline & \multicolumn{5}{|c|}{ Number of secondary branches } & \multicolumn{5}{|c|}{ Tassel branch number } \\
\hline & D5 & $\mathrm{D} 10$ & D20 & $\mathrm{D} 30$ & $\mathrm{D} 40$ & D5 & D10 & $\mathrm{D} 20$ & D30 & D40 \\
\hline $20 \mathrm{~A} 55$ & $234^{\mathrm{b}}$ & 59 & 15 & 7 & 4 & $89^{\mathrm{a}}$ & 23 & 6 & 3 & 1 \\
\hline $30 \mathrm{~A} 68$ & $368^{\mathrm{b}}$ & 92 & 23 & 11 & 6 & $68^{\mathrm{a}}$ & 17 & 5 & 2 & 1 \\
\hline $30 \mathrm{~F} 53$ & $860^{\mathrm{b}}$ & 215 & 54 & 24 & 14 & $89^{\mathrm{a}}$ & 23 & 6 & 3 & 1 \\
\hline AG8780 & $168^{\mathrm{b}}$ & 42 & 11 & 5 & 3 & $28^{b}$ & 7 & 2 & 1 & 1 \\
\hline AG9025 & $1547^{\mathrm{b}}$ & 387 & 97 & 43 & 25 & $115^{\mathrm{a}}$ & 29 & 8 & 4 & 1 \\
\hline AM9724 & $246^{\mathrm{b}}$ & 62 & 16 & 7 & 4 & $61^{\mathrm{b}}$ & 16 & 4 & 2 & 1 \\
\hline AS1666 & $314^{\mathrm{b}}$ & 79 & 20 & 9 & 5 & $46^{\mathrm{b}}$ & 12 & 3 & 2 & 1 \\
\hline AS1677 & $478^{\mathrm{b}}$ & 120 & 30 & 14 & 8 & $79^{\mathrm{a}}$ & 20 & 5 & 3 & 1 \\
\hline BM3066 & $226^{\mathrm{b}}$ & 57 & 15 & 7 & 4 & $46^{\mathrm{b}}$ & 12 & 3 & 2 & 1 \\
\hline Celeron & $214^{\mathrm{b}}$ & 54 & 14 & 6 & 4 & $39^{\mathrm{b}}$ & 10 & 3 & 2 & 1 \\
\hline DKB230 & $253^{\mathrm{b}}$ & 64 & 16 & 8 & 4 & $40^{\mathrm{b}}$ & 10 & 3 & 2 & 1 \\
\hline DKB290 & $167^{\mathrm{b}}$ & 42 & 11 & 5 & 3 & $23^{\mathrm{b}}$ & 6 & 2 & 1 & 2 \\
\hline MS2010 & $380^{\mathrm{b}}$ & 95 & 24 & 11 & 6 & $74^{\mathrm{a}}$ & 19 & 5 & 3 & 2 \\
\hline MS2013 & $254^{\mathrm{b}}$ & 64 & 16 & 8 & 4 & $44^{\mathrm{b}}$ & 11 & 3 & 2 & 2 \\
\hline MS3022 & $230^{\mathrm{b}}$ & 58 & 15 & 7 & 4 & $67^{\mathrm{a}}$ & 17 & 5 & 2 & 2 \\
\hline P1630 & $6251^{\mathrm{a}}$ & 1563 & 391 & 174 & 98 & $107^{\mathrm{a}}$ & 27 & 7 & 3 & 2 \\
\hline P2530 & - & - & - & - & - & $76^{\mathrm{a}}$ & 19 & 5 & 3 & 2 \\
\hline SHS7915 & $236^{\mathrm{b}}$ & 59 & 15 & 7 & 4 & $45^{\mathrm{b}}$ & 12 & 3 & 2 & 2 \\
\hline StatusVIP & $161^{\mathrm{b}}$ & 41 & 11 & 5 & 3 & $36^{\mathrm{b}}$ & 9 & 3 & 1 & 2 \\
\hline SX7331 & $172^{\mathrm{b}}$ & 43 & 11 & 5 & 3 & $31^{\mathrm{b}}$ & 8 & 2 & 1 & 2 \\
\hline Mean & 672 & 169 & 43 & 20 & 11 & 61 & 16 & 5 & 3 & 2 \\
\hline
\end{tabular}

Means not followed by the same superscript letter differ by the Scott-Knott test at a $5 \%$ significance level. In columns referring to D10, D20, D30, and D40, the superscript letters are the same as in the column referring to D5, and therefore, are not shown.

Genetics and Molecular Research 15 (4): gmr15049151 
If the researcher selects the largest average number of sample size (NSB trait), 11, 20, and 43 tassels are sufficient to estimate the mean values for tassel traits with a precision of $40 \%$ (D40), 30\% (D30), and 20\% (D20), respectively, of the mean estimate and a 95\% confidence level. Taking the average sample size for genotypes in groups of traits for a precision of $10 \%$ (D10) of the estimated mean, weight traits (PDM, BSDM, CSDM, and TDM) can be sampled with 32 tassels (Table 3), length traits (PL, BSL, CSL, and TL) with 22 tassels (Table 4), and branching traits (NPB, NSB, and TBN) with 169 tassels. Furthermore, assuming that the sample size is set at 43 tassels (20\% precision) to estimate the mean values of treatments in an experiment with three replicates, 15 tassels can be sampled by repetition.

In conclusion, for tassel traits, 11, 20, and 43 tassels are sufficient to estimate the mean with a precision of 40,30 , and $20 \%$, respectively, of the estimated mean at a $95 \%$ confidence level.

There is sample size variability among maize genotypes for peduncle dry matter, central spike dry matter, tassel dry matter, peduncle length, branching space length, central spike length, tassel length, number of primary branches, number of secondary branches, and tassel branch number.

\section{Conflicts of interest}

The authors declare no conflict of interest.

\section{ACKNOWLEDGMENTS}

We thank Conselho Nacional de Desenvolvimento Científico e Tecnológico (CNPq), Coordenação de Aperfeiçoamento de Pessoal de Nível Superior (CAPES), Fundação de Amparo à Pesquisa do Estado do Rio Grande do Sul (FAPERGS) for granting scholarships.

\section{REFERENCES}

Allard RW (1999). Principles of plant breeding. 2nd edn. John Wiley and Sons, New York.

Andrade JAC and Miranda Filho JB (2008). Quantitative variation in the tropical maize population, ESALQ-PB1. Sci. Agric. 65: 174-182. http://dx.doi.org/10.1590/S0103-90162008000200011

Barbin D (2003). Planejamento e análise estatística de experimentos agronômicos. Midas, Arapongas.

Brewbaker JL (2015). Diversity and genetics of tassel branch numbers in maize. Crop Sci. 55: 65-78. http://dx.doi. org/10.2135/cropsci2014.03.0248

Bussab WO and Morettin PA (2011). Estatística básica. 7th edn. Saraiva, São Paulo.

Cargnelutti Filho A, Toebe M, Burin C, Silveira TR, et al. (2010). Sample size for estimating the Pearson correlation coefficient among corn characters. Pesqui. Agropecu. Bras. 45: 1363-1371.

Cargnelutti Filho A, Toebe M, Burin C, Fick AL, et al. (2012). Sample size for estimating the average length, diameter and weight of seeds of jack bean and velvet bean. Cienc. Rural 42: 1541-1544. http://dx.doi.org/10.1590/S0103$\underline{84782012005000057}$

Cruz CD (2013). Genes - a software package for analysis in experimental statistics and quantitative genetics. Acta Sci. Agron. 35: 271-276. http://dx.doi.org/10.4025/actasciagron.v35i3.21251

Duvick D (2005). Genetic progress in yield of United States maize (Zea mays L.). Maydica 50: 193-202.

Edwards J (2011). Changes in plant morphology in response to recurrent selection in the Iowa Stiff Stalk synthetic maize population. Crop Sci. 51: 2352-2361. http://dx.doi.org/10.2135/cropsci2010.09.0564

Fischer RA and Edmeades GO (2010). Breeding and cereal yield progress. Crop Sci. 50: 85-98. http://dx.doi.org/10.2135/ cropsci2009.10.0564

Food and Agriculture Organization of the United Nations (FAO) (2016). Agricultural Market Information System statistics.

Hallauer AR, Carena MJ and Miranda Filho JB (2010). Quantitative genetics in maize breeding. 3rd edn. Springer-Verlag New York, New York.

Genetics and Molecular Research 15 (4): gmr15049151 
Heldwein AB, Buriol GA and Streck NA (2009). O clima de Santa Maria. Cienc. Amb. 38: 43-58.

Lauer S, Hall BD, Mulaosmanovic E, Anderson SR, et al. (2012). Morphological changes in parental lines of pioneer brand maize hybrids in the U.S. Central Corn Belt. Crop Sci. 52: 1033-1043.

Martin TN, Storck L, Lúcio AD and Lorentz LH (2005). Sampling plan in corn plots to evaluate ear characteristics. Cienc. Rural 35: 1257-1262. http://dx.doi.org/10.1590/S0103-84782005000600005

Modolo AJ, Storck L, Trogello E and Cassol LC (2013). Sample size determination for maize plants and cob traits under straw management at sowing. Maydica 58: 151-155.

Nardino M, Souza VQ, Baretta D, Konflanz VA, et al. (2016a). Partial diallel analysis among maize lines for characteristics related to the tassel and the productivity. Afr. J. Agric. Res. 11: 974-982. http://dx.doi.org/10.5897/AJAR2014.10314

Nardino M, Souza VQ, Baretta D, Konflanz VA, et al. (2016b). Association of secondary traits with yield in maize F1's. Cienc. Rural 46: 776-782. http://dx.doi.org/10.1590/0103-8478cr20150253

Peel MC, Finlayson BL and McMahon TA (2007). Updated world map of the Köppen-Geiger climate classification. Hydrol. Earth Syst. Sci. 11: 1633-1644. http://dx.doi.org/10.5194/hess-11-1633-2007

Resende MDV and Duarte JB (2007). Precision and quality control in variety trials. Pesqui. Agropecu. Trop. 37: 182-194.

Ribeiro CB, Ramalho MAP and Prado PER (2014). Contribution of vegetative and reproductive traits of maize plant to heterosis in grain production. Rev. Bras. Milho. Sorgo 13: 59-68. http://dx.doi.org/10.18512/1980-6477/rbms. v13n1p59-68

Sangoi L, Guidolin AF, Coimbra JLM and Silva PRF (2006). Response of maize hybrids grown at different eras to plant population and tassel removal. Cienc. Rural 36: 1367-1373. http://dx.doi.org/10.1590/S0103-84782006000500004

Santos HG, Jacomine PKT, Anjos LHC, Oliveira VA, et al. (2013). Sistema brasileiro de classificação de solos. 3rd edn. Embrapa, Brasília.

Scott AJ and Knott M (1974). A cluster analysis method for grouping means in the analysis of variance. Biometrics 30: 507-512. http://dx.doi.org/10.2307/2529204

Siegel S and Castellan Júnior NJ (2006). Estatística não-paramétrica para ciências do comportamento. 2nd edn. Artmed, Porto Alegre.

Storck L, Lopes SJ, Cargnelutti Filho A, Martini LFD, et al. (2007). Sample size for single, double and thee way hybrid corn ear traits. Sci. Agric. 64: 30-35. http://dx.doi.org/10.1590/S0103-90162007000100005

Storck L, Garcia DC, Lopes SJ and Estefanel V (2016). Experimentação vegetal. 4th edn. UFSM, Santa Maria.

Toebe M, Cargnelutti Filho A, Burin C, Casarotto G, et al. (2014). Sample size for the estimation of the mean and the coefficient of variation in maize. Pesqui. Agropecu. Bras. 49: 860-871. http://dx.doi.org/10.1590/S0100$\underline{204 X 2014001100005}$

Toebe M, Cargnelutti Filho A, Lopes SJ, Burin C, et al. (2015). Sample size in the estimation of correlation coefficients for corn hybrids in crops and accuracy levels. Bragantia 74: 16-24. http://dx.doi.org/10.1590/1678-4499.0324

Upadyayula N, da Silva HS, Bohn MO and Rocheford TR (2006). Genetic and QTL analysis of maize tassel and ear inflorescence architecture. Theor. Appl. Genet. 112: 592-606. http://dx.doi.org/10.1007/s00122-005-0133-x

Genetics and Molecular Research 15 (4): gmr15049151 